\title{
A CASE OF MALIGNANT GROWTH OF THE UVULA.*
}

BY F. C. RAYNOR, M D.,

Surgeon, Throat Department of the Brooklyn Eye and Ear Hospital.

Malignant neoplasms of the uvula are of very rare occurrence. As an illustration thereof, I may state that in my fiftecn years service in the throat department of the Brooklyn Eye and Ear Hospital, embracing some 14,000 cases, none such has been encountered. The following, therefore, seems worthy of being placed on record.

Mr. S., aged 66 years, first consulted me June 12, 1901, being referred to me by Dr. F. C. Paffard. He complained of a constant irritation of the throat, an inability to sleep except when lying on the right side, owing, as he described it, to shortness of breath, and an escape of saliva when in the recumbent posture. He had an attack of grip in January, of the catarrhal form, but his throat dicl not trouble him especially, till March, since which time his cliscomfort has been continuous and increasing. 'The' patient was of fine physigue and good general health, and there was no family history of malignant disease. His uvula was amputated thirty-five years ago, and he had antral suppuration fiftecn years ago, which was cured by chainage through an alveolar puncture.

On examination I found an elongated and elematous uvula, behind which was a nodular mass, strongly suggesting a pharyngeal adenoid. Further examination showed that this mass was connected to the posterior surface of the uvula, its upper margin terminating on a line with the velum, extending about one-fourth of an inch on each side, and about half an inch below the tip of the uvula, the whole forming a flattened cylinder about one inch long, threefourths of an inch wide and half an inch thick. It was slightly eroded at the end. There was no interference with deglutition or phonation. Examination was clifficult, owing to the natural formation and extreme irritability of the part, but I finally satisfied myself that there was no further pharyngeal involvement. The nose was also free from any growth. Altrougl there was nothing

* Read before the Kings Connty Mredical Association, Jau. 14th, 1902. 


\section{RAYNOR: A CASE OF MALIGNANT GROWTH OF THE UVULA.}

to inclicate syphilis, as a matter of precaution, anti-specific treatment was instituted, and local cletergent, and sedative applications ordered. The result of the foregoing being negative, operative methods were resorted to. June 28 the growth was removed by the cold snare, under ether anesthesia administered by Dr. Paffard. It. was intended to employ the galvano-cautery loop, but even under deep anesthesia the irritability was so extreme that it was impossible to safeguard the surrounding tissues, therefore this procedure hacl to be abancloned. The growth was snared off well above its point of inception, the operation was practically bloodless, and healing prompt and uneventful. The growth was photographed and submitted to a pathologist with the request that the specimen be preserved.

Unfortumately the plate proved defective, and the pathologist inalvertently neglected to preserve the growth, so that I am mable to show you the existing conditions as I intended. Although the advanced age of the paticnt favored the probability of malignancy, still the absence of symptoms characteristic of malignant growths, i. c.. pain, hemorrhage, adenopathy, cachexia, etc., led me to hope that this was benign in character. This idea was strengthened by an experience I lad some years ago, when a growth of very similar appearance and behavior, having its origin at the base of the tongue, proved to be benign, although the pathologist reported it as malignant.

Knowing the beneficent effect of arsenic, in epithelial and sarcomatous growths, as exemplified in the teaching and practice of my colleague, Dr. S. Sherwell, as a matter of precaution, I at once put my patient under the influence of the drug; which was so illy borne, that the (quantity acministered was comparatively small. After considerable delay the report of the pathologist was received. It was extremely guarded, and was to the effect that the growth was atypical, was in all probability malignant, and the examiner was disposed to class it among the carcinomata.

The history of the case subsequent to the operation, is as follows: The patient was seen at intervals of one to two weeks. There were no subjective or objective symptoms till about October I, when, after his summer sojourn in the mountains, he returned to the city and contracted a cold. He then complained of a sore throat, but there were no signs of recurrence, only those of a general pharyngeal inflammation. The usual treatment for such con- 
clitions gave no relief. He continued to complain of severe pain. referring it to the base of the tongue and, larynx, although nothing could be seen. On December 6, after a two-weeks' interval I cliscovered a small fungous growth just to the left of the site of the operation. growing downward from the border of the velum. Four days later a localized swelling on the hard palate to the right of the median line, about a half inch in diameter was observed, together with a linear erosion, extending upward from the fungous growth above mentioned.

At the solicitation of friends, the patient moved to Manhattan the following week, for treatment by the X-ray.

66 Livingston St.

\section{Case of a Parasite-"Argas (or Ornithodorus) Meguini " (Dujes)}

-in Each Ear. J. C. Simpson. "Lancet," April 27, 1901.

A patient brought the author a living specimen of this tick, which he said had come from his right ear of its own accord on the previous day. Nothing abnormal was found in that ear, but on removing some wax from the other a parasite similar to, but smaller than, the other specimen was plainly visible closely applied to the clrum. As it is very important not to leave any portion of the suckers or hooks in the tissues, more especially in the drum, by soaking a small pledget of wadding with chloroform, and inserting it into the canal for a few seconds, the tick was rapiclly killed, and was easily removed by syringing. On examination, it was found to be entire, and no injury was visible to the drum of either ear.

The previous history of the patient was that he had camped out in Arizona in the month of June. He returned to his loome in Massachusetts, U. S. A., at the end of that month, and then "had some curious sensations in the left ear, a sort of pain above the ear, and a rattling sound in the ear. These feelings decreased and had almost passed away, though the rattling was occasionally heard" up to August 25, when the live parasite came from the right ear, which apparently had not been the subject of any striking abnormal sensations.

The article is illustrated by drawings of the parasite. It is about three-sixtecnths of an inch in length, and the magnification of the photograph is slightly over $\times 6$. The larger living specimen was more than clouble this size, and broad and thick in proportion. In color and general appearance its body resembled an unroasted coffee bean. 